\title{
Removal of Selenium (Se) and Zinc (Zn) in Water by Using Natural Zeolitic Tuff as Adsorbent from Tegalrejo Area, Gedangsari District, Gunungkidul Regency, Special Province Yogyakarta, Indonesia
}

\author{
Manixone Thepgnothy ${ }^{* 1}$, Doni Prakasa Eka Putra ${ }^{2,3}$, and Wahyu Wilopo ${ }^{2,3}$ \\ ${ }^{1}$ Department of Environmental Engineering, Faculty of Engineering, National University of Lao \\ ${ }^{2}$ Department of Geological Engineering, Faculty of Engineering, Gadjah Mada University, Yogyakarta, Indonesia \\ ${ }^{3}$ Center for Disaster Mitigation and Technological Innovation (GAMA-InaTEK), Universitas Gadjah Mada
}

\begin{abstract}
Heavy metals are one of the most hazardous pollutant in the water. There are many methods for heavy metals remediation such as precipitation, oxidation, reverse osmosis, ion exchange and sorption by reactive materials. Zeolite is one of reactive materials have been used for water remediation. Therefero, in this the capability of zeolite from Gedangsari District, Gunung Kidul Regency, Special Province of Yogyakarta, Indonesia, will be invetigated to remidiate contaminated water by selenium (Se) and Zinc (Zn). To answer this objective, several samples of natural zeolitic tuff were taken and charaterized. Laboratory experiment was done by batch test. The results showed that natural zeolitic tuff is an effective adsorbent of Se and $\mathrm{Zn}$ and holds great potential material to remove heavy metals in water. The sorption isotherms of Se and Zn confirmed to type of Langmuir or Freundlich isotherms.
\end{abstract}

Keywords: Natural zeolitic tuff · Selenium $\cdot$ Zinc $\cdot$ Sorption isotherm · Indonesia.

\section{INTRODUCTION}

Nowadays, the world is facing water crisis due to lacking of clean drinking water and heavy metal are considered as one of hazardous pollutants, due to their toxicity, even at low concentration. Urbanization, industrialization and also mining activities are commonly recognized as the cause of environmental deterioration due to the release or leakage of heavy metal contaminant into the body of water (Wilopo et al., 2010). The increasing level of heavy metals in natural water bodies poses a serious threat to living species including humans. The heavy metals, such as lead $(\mathrm{Pb})$, zinc $(\mathrm{Zn})$, copper $(\mathrm{Cu})$, cadmium $(\mathrm{Cd})$, Mercury $(\mathrm{Hg})$, Arsenic (As) are major toxic pollutants and these poisonous substances are likely to infiltrate into unsaturated zone, leading to groundwater contamination.

\footnotetext{
${ }^{*}$ Corresponding author: M. THEPGNOTHY, Department of Environmental Engineering, Faculty of Engineering, National University of Lao. E-mail: thepgnothy.manixone@gmail.com
}

In nature, some materials containing adsorption and natural ion exchange properties are capable of removing water contaminant. Most of these natural ion exchange materials are made up of crystalline aluminosilicates framework composed of $(\mathrm{Si}, \mathrm{Al}) \mathrm{O}_{4}$ Tetrahedral with cation exchange properties (Koohsaryan et al., 2016). Zeolite is one of the most popular materials contain natural ion exchange, and it has capable of removing contaminants have been investigated in a number of studies (Ozekmekci et al., 2015).

Near Yogyakarta region, there is an area contain deposits of zeolite or zeolitic tuff (Widiasmoro \& Wintolo, 2000). This area is called Gedangsari District, Gunung Kidul, Yogyakarta. The occurence of zeolite is correlated with the weathering results of tuff formation existing on Kebo Butak and Semilir Fornation (Irien, 2011). The zeolitic tuff occur on this area is consists of clinoptilolite, clay mineral (montmorillonite, chlorite), feldspar and quarts (Widiasmoro \& Wintolo, 2000; Yuminti, 
2005; Fatkhiandari and Warmada, 2011) and the XRF analysis of the zeolitic tuff show that $\mathrm{SiO}_{2}$ is the dominan composition followed by $\mathrm{Al}_{2} \mathrm{O}_{3}, \mathrm{CaO}, \mathrm{FeO}, \mathrm{Na}_{2} \mathrm{O}, \mathrm{MgO}, \mathrm{K}_{2} \mathrm{O}$ (Idrus et al., 2008). Some properties of zeolitic tuff in the research area are;densities are relatively low (1.34-1.74 $\left.\mathrm{gr} / \mathrm{cm}^{3}\right)$, water adsorption are wide range of values varying from 13.42 to $27.60 \%$, initial cation excange capacity (CEC) of natural zeolitic tuffs vary from 39.41 to 67.84 mg $\mathrm{Na}_{2} \mathrm{O} / 100$ gr zeolite and acidities (represented by $\mathrm{pH}$ values) are slight alkali with $\mathrm{pH}$ ranging from 7.3 to 8.3 (Idrus et al., 2008). An analysis of surface area by using Brunauer Emmet Teller (BET) method of this zeolitic tuff is found to be $72 \mathrm{~m}^{2} \mathrm{~g}^{-1}$ (Wilopo, 2010).

Due to its properties, some researcher have been tried to use the zeolite or zeolitif tuff from Gedangsari District to adsorb heavy metal of $\mathrm{Cu}$ and $\mathrm{Pb}$ in water (Wilopo, 2010; Buncheon et al., 2010). The results show the zeolitic tuff from this area can become an effective adsorbent for $\mathrm{Cu}$ and $\mathrm{Pb}$. However, question occur regarding the capability of the material to adsorb other kind of heavy metals. Therefore, on this research, selenium and zinc solution are become the target metals to be remove by the natural zeolitic tuff. Selenium is choosen as it has difference sorption behaviour with group of transition metals (ex. $\mathrm{Zn}, \mathrm{Pb}$ ) under common oxidation-reduction conditions (Eby, 2004) and this research attempts also to know the sorption behavior of those heavy metals by the zeolitic tuff material.

\section{THEORETICAL BACKGROUND}

\subsection{Zeolite}

The natural zeolites are large group of (cluster silicate) aluminosilicate minerals of a porous structure with valuable physiochemical properties, such as cation exchange, molecular sieving, catalysis and sorption(Wang \& Peng, 2010; Ghorbanloo et al., 2015). Most common natural zeolite is formed by alteration of glass-rich volcanic rocks (tuff). The structure of zeolite consists of three-dimensional framework of $\mathrm{SiO}^{4+}$ and also $\mathrm{AlO}^{4+}$ tetrahedral. The aluminum ion is small enough to occupy the position in the center of the tetrahedron of four oxygen atoms, and the isomorphs replacement of $\mathrm{Al}^{3+}$ by $\mathrm{Si}^{4+}$ raises a negative charge in the lattice (Erdeem $e t$ al., 2004).

The use of natural zeolites for environmental applications is gaining new research interests mainly due to their properties and significant worldwide occurrence. Natural zeolites have advantages over cation exchange materials such as commonly used organic resins, because they are cheap, they exhibit excellent selectivity for different cation at low temperature, which is accompanied with a release of nontoxic exchangeable cations $\left(\mathrm{K}^{+}, \mathrm{Na}^{+}, \mathrm{Ca}^{2+}\right.$ and $\mathrm{Mg}^{2+}$ ) to the environment, they are compact in size and they allow simple and cheap maintenance in the full-scale applications. The efficiency of water and wastewater treatment by using natural and modified zeolites depends on the type and quantity of the used zeolite, the size distribution of zeolite particles, the initial concentration of contaminants (cation/anion), $\mathrm{pH}$ value of solution, ionic strength of solution, temperature, pressure, contact time of system zeolite/solution and the presence of the other organic compounds and anions (Wang \& Peng, 2010; Margeta et al., 2013).

\subsection{Sorption isoterm}

Sorption processes include adsorption, chemisorption, absorption and ion exchange. Sorption is determined experimentally by measuring how much of a solute can be sorbed by particular sediment, soil and rock type either by batch test or column test. The capacity of a solid to remove a solute is a function of the concentration of the solute. The results of experiment are plotted on a graph, called an isoterm, that shows the solute concentration versus the amount sorbed onto the the solid (Fetter, 1999). There are three kind of isoterm graph; linear sorption isotherm, freundlich sorption isotherm and langmuir sorption isotherm. Linear sorption isoterm, if there is a direct, linear relationship between the amount of a solute sorbed onto solid, $q$ and the concentration of the solute, $C_{e}$ (Fetter, 1999). The resulting linear sorption isotherm is described by the equation 1.

$$
q=K_{d} \cdot C_{e}
$$

where, $q$ is mass of solute sorbed per dry unit weight of solid $(\mathrm{mg} / \mathrm{kg}), C_{e}$ is concentration of 
solute in solution in equilibrium with the mass of solute sorbed onto the solid $(\mathrm{mg} / \mathrm{L})$, and $K_{d}$ is distribution coefficient $(\mathrm{L} / \mathrm{kg})$.

Freundlich sorption isotherm, if there is a non linear relationship/curvilinear relationship occur between $q$ versus $C_{e}$ (Fetter, 1999), and equation 2.

$$
q=K \cdot C_{e}^{N}
$$

However the data can be linearized by use of the equation .3

$$
\log q=\log K+N \log q
$$

Langmuir sorption isoterm, if there is also a non linear relationship occur between $C *$ versus $C$. The solid isassumed to have a limited adsorption capacity qm. All the adsorption sites are assumed to be identical, each site retains one molecule of the given compound, and all sites areenergetically and sterically independent of the adsorbed quantity (Limousin et al., 2007). The langmuir adsorption equation is expressed as equation 4 .

$$
q=\frac{q_{m} K_{d} C_{e}}{1+Q_{\max } C_{e}}
$$

A linear form this equation can rewrite as equation 5 .

$$
\frac{C_{e}}{q}=\frac{1}{q_{m} K_{d}}+\frac{C_{e}}{q_{m}}
$$

\subsection{Heavy metals: $\mathrm{Zn}$ and Se}

Heavy metals are those metals of atomic number 20 and greater. Heavy metals can be differentiated into three groups: (1) transition metals, $\mathrm{Zn}, \mathrm{Cd}$ and $\mathrm{Pb}$; (2) As and Se (metalloids) and (3) $\mathrm{Hg}$ (Eby, 2004). For transition metals, including $\mathrm{Zn}, \mathrm{Cd}$ and $\mathrm{Pb}$, if they under most oxidation-reduction condition these elements occur in solution as divalent or trivalent cationic species. Arsen and selenium differ from the transition metals in that they occur in solution as neutral and negatively charged species under most oxidation-reduction condition in water.

In water, the factors that control heavy metals mobility are $\mathrm{pH}, \mathrm{Eh}$, the presence of organic compounds and the presence of suitable sorbates (e.g., Mn and Fe oxyhydroxides). For transition metals (e.g., $\mathrm{Zn}$ ), at low $\mathrm{pH}$, sorption is negligible, but when increasing $\mathrm{pH}$, sorption becomes an important process. Because Se exist in solution as negatively charged species, sorption is increase with declining $\mathrm{pH}$, and selenium tends to remain in solution under oxydizing conditions but removed under reducing conditions (Eby, 2004).

\section{MATERIALS AND Methods}

\subsection{Materials and characterization}

A total of six samples of natural zeolitic tuff were taken from Tegalrejo area, Gedangsari District, Gunung Kidul Regency, Special Province Yogyakarta (Indonesia) showed on Figure 1. Non-crushed materials were used for mineralogical and chemical characterization such as XRD (X-ray Diffraction) and SEM (Scanning Electron Microscope) analysis. Results of characterization are described below.

The XRD analysis of the samples show the peaks of diffraction are belonging to clinoptilolite, mordenite and smectite, and also the other minerals including plagioclase and quartz (see Figure 2). The presences of mordenite are also well recognized by SEM analysis, illustrated by Figure 3. respectively. Mordenite and clinoptilolite (zeolite minerals) are mostly characterized by needles/fibers structures as seen in Figure 3. Based on the XRD and SEM analysis, it is proved that the material from Gedangsari district used on this research is not a pure zeolite minerals but zeolitic tuff materials. Futhermore, sorption capacity of the materials can be expected not only generated by zeolite minerals but also due to occurence of clay mineral's smectite.

\subsection{Batch test}

The sorption of heavy metal on natural zeolitic tuff was carried out by using batch method. For this test, the materials was crushed gently and sieved to get similar grain size of 1.18 $\mathrm{mm}$ and then dried in an oven at $60^{\circ} \mathrm{C}$ for 24 hours. Batch adsorption experiments were conducted by using five differences grams of zeolitic tuff (1gr, 5 gr, 10 gr, 15 gr and 30 gr) of adsorbent with $300 \mathrm{~mL}$ of solution containing with $7.67 \mathrm{mg} / \mathrm{L}$ Se adnd $7 \mathrm{mg} / \mathrm{L}$ of $\mathrm{Zn})$. All solution contain of Se and $\mathrm{Zn}$ were shaking for 48 hours at $100 \mathrm{rpm}$ with constant $25^{\circ} \mathrm{C}$ tempera- 


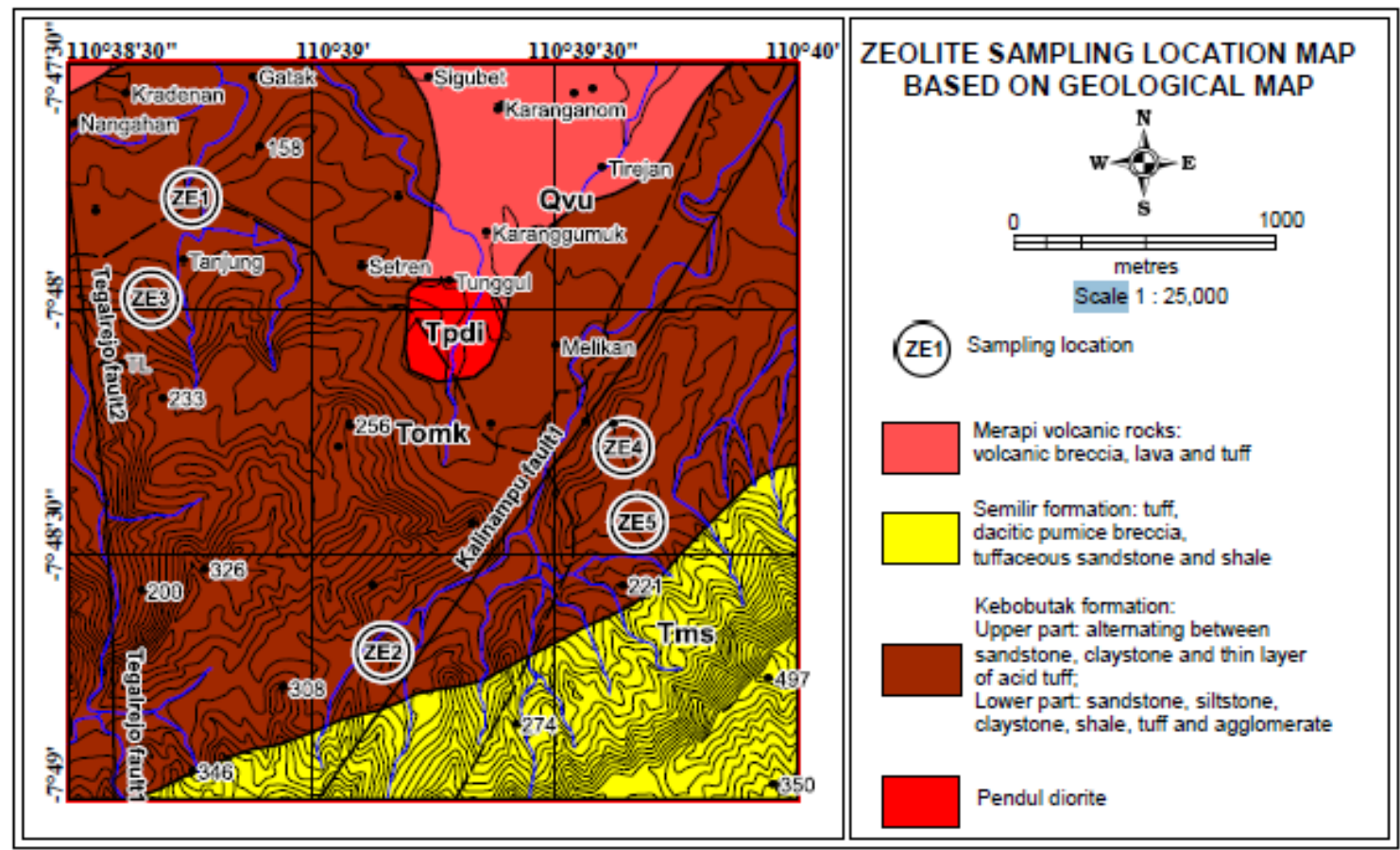

Figure 1: Location of zeolitic tuff sampling area in the Gedangsari District, Gunung Kidul, Yogyakarta, Indonesia.

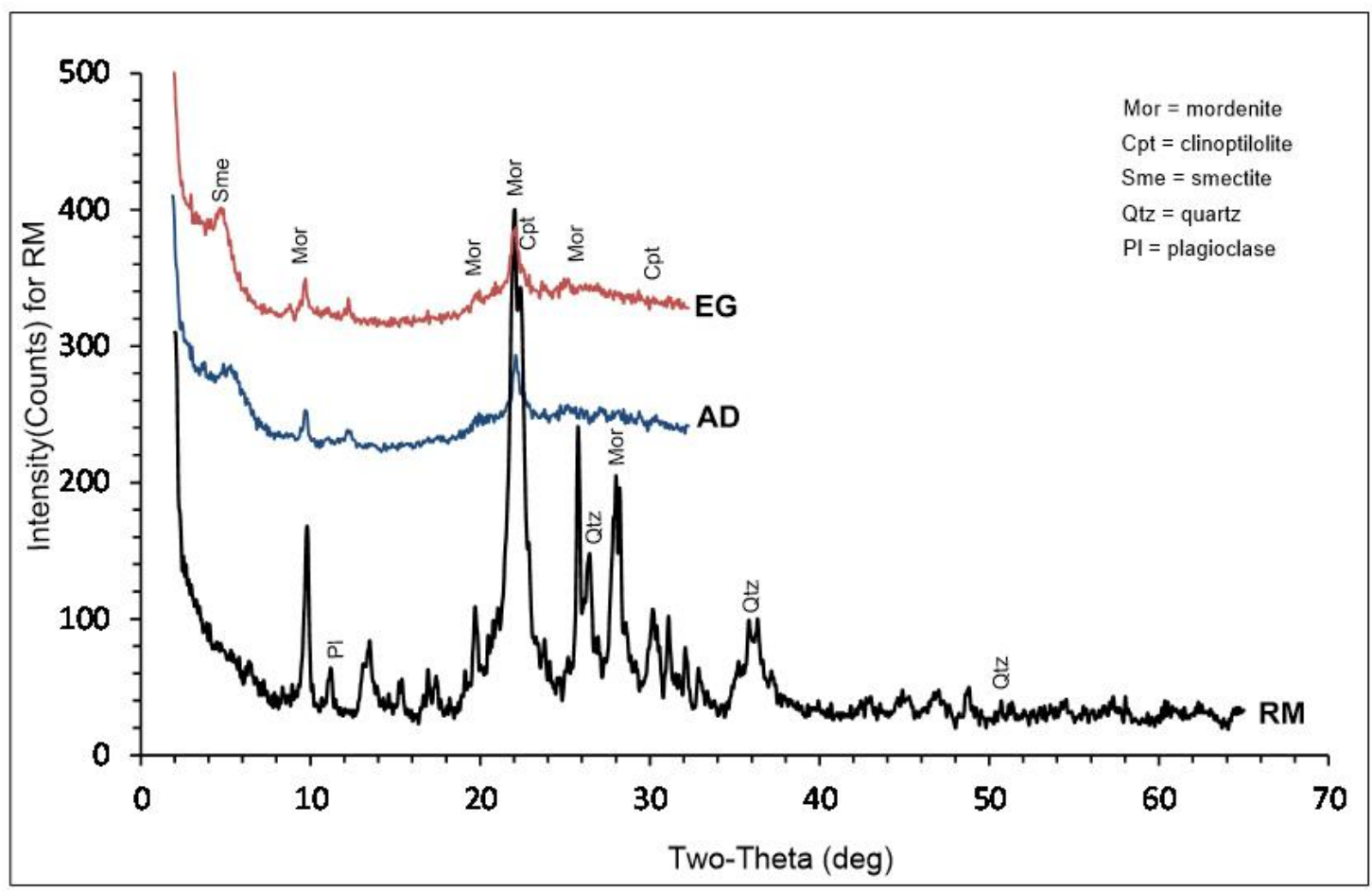

Figure 2: Result of XRD analysis showing the presence of mineral phases, including zeolite minerals, Mordenite (Mor), Clinoptilolite (Cpt), Smectite (Smc), Quartz (Qtz) and Plagioclase (Pl). 


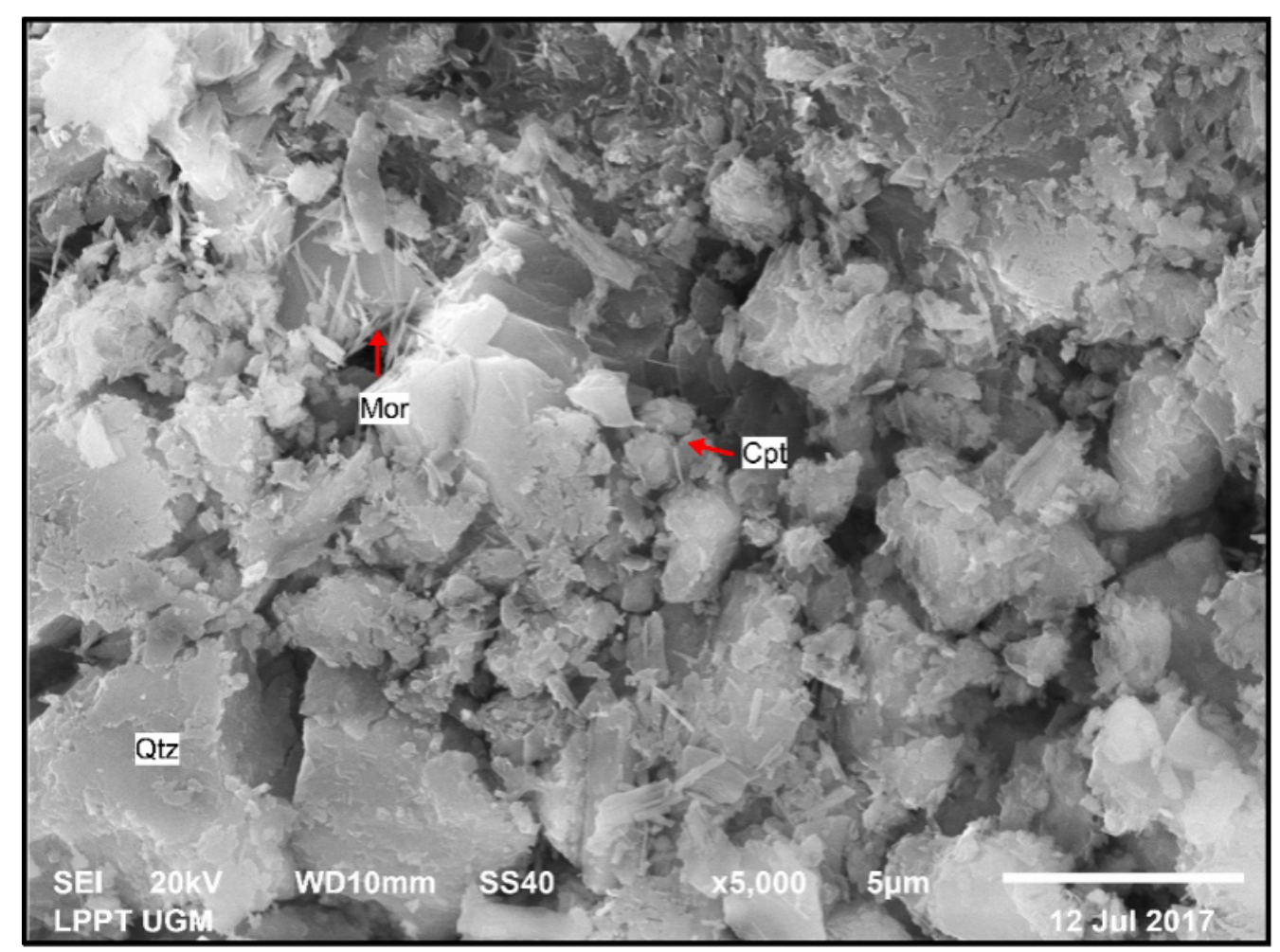

Figure 3: Scanning electron micrograph of modernite (fiber shape) and clinoptilolite (tabular euhedral) in zeolitic tuff from Gedangsari district, GunungKidul, Special Province Yogyakarta, Indonesia.

ture condition. Initial $\mathrm{pH}$ condition for both test of heavy metals is on acid condition to represent acid mine water condition. During shaking, solution samples were taken at defined step of time. The solution containing of Se and $\mathrm{Zn}$ were filtered through by $0.20 \mu \mathrm{m}$ Syringe Filter. Se and $\mathrm{Zn}$ concentration were determined by AAS (Atomic Adsorption Spectrometry) method.The percent of sorption was calculated by using the equation 6.

$$
\% \text { adsorption }=\frac{C_{i}-C_{f}}{C_{f}} \times 100
$$

where $C_{i}$ and $C_{f}$ are the concentration of the metal ion in initial and final solution, respectively.

\section{Results AND Discussion}

\subsection{Effect of time and amount of zeolitic tuff to sorption capacity}

The sorption capacity of selenium (Se) on this research are shown in Figure 4 and Figure 5. Based on Figure 4, the graph suggest that the reaction time had strong impact to the efficiency and capacity of sorption process to remove Selenium (Se) in water. The result shown that

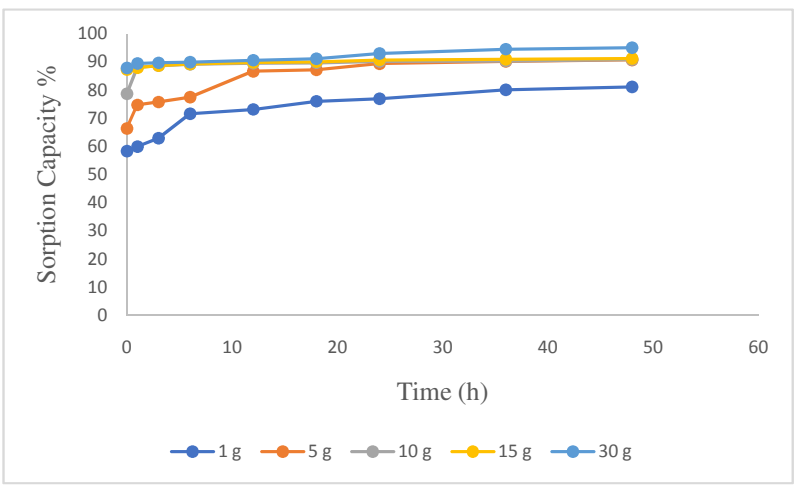

Figure 4: Sorption capacity of Se versus time on different amount of zeolitic tuff.

the highest amount of zeolitic tuff (30 gr) reveals good capacity of selenium sorption. The sorption capacity can reach up to $95 \%$ during 48 hours from initial concentration.

In the Figure 5, it is clear that the heavier amount of zeolitic tuff put in, the more higher the concentration of selenium adsorbed to the zeolitif tuff. For example, 30 gr of zeolitic tuff with the initial concentration of Se in the water is $7.67 \mathrm{mg} / \mathrm{L}$ reveals after 48 hours only 0.38 $\mathrm{mg} / 1$ left in the water. Almost similar result also seen for Zinc, as shown in Figure 6 and 


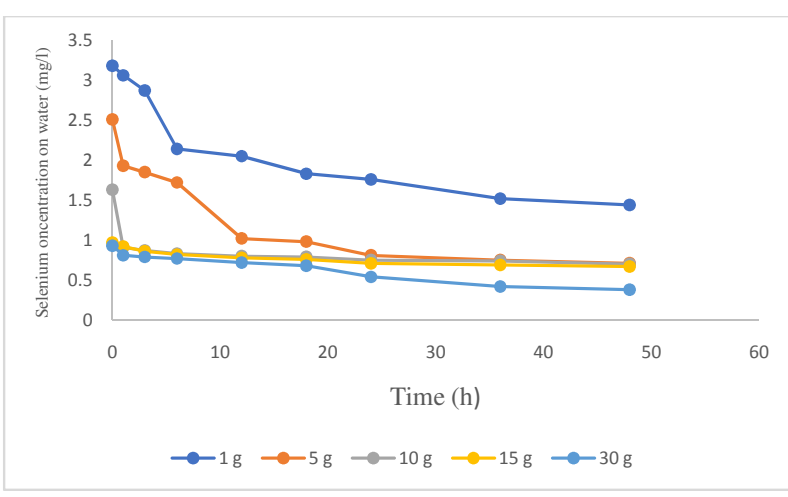

Figure 5: Selenium concentration versus time on different amount of zeolitic tuff.

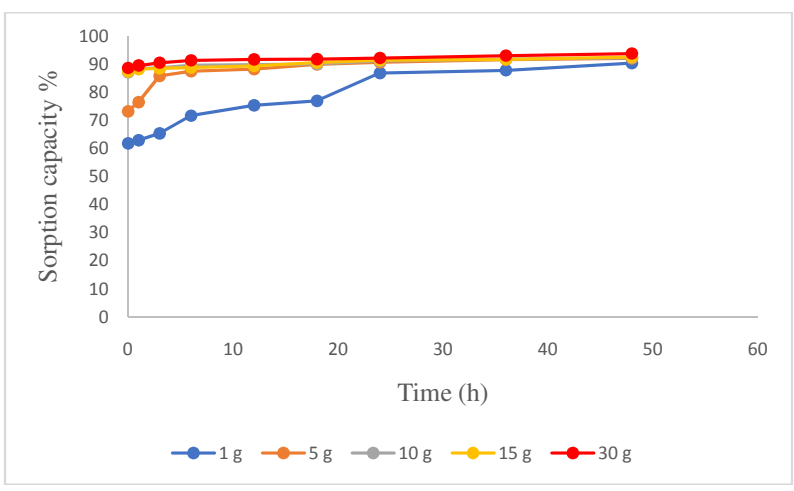

Figure 6: Sorption capacity of $\mathrm{Zn}$ versus time on different amount of zeolitic tuff.

Figure 7. As seeen on Figure 6, the sorption capacity of Zinc can reach up to $93.8 \%$ during 48 hours and with 30 gr of zeolitic tuff and initial concentration of $7.0 \mathrm{mg} / \mathrm{l}$, after 48 hours, the concentration of $\mathrm{Zn}$ in the water was only 0.43 $\mathrm{mg} / 1$.

According to Figure 4 to Figure 7, it can be summarized that both Se and Zn solution show similar pattern of graph. Actually, in the begin-

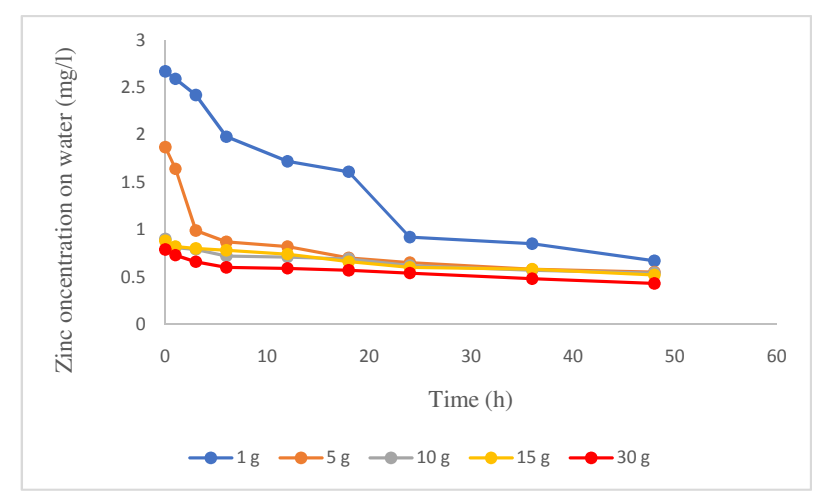

Figure 7: Zinc concentration versus time on different amount of zeolitic tuff.

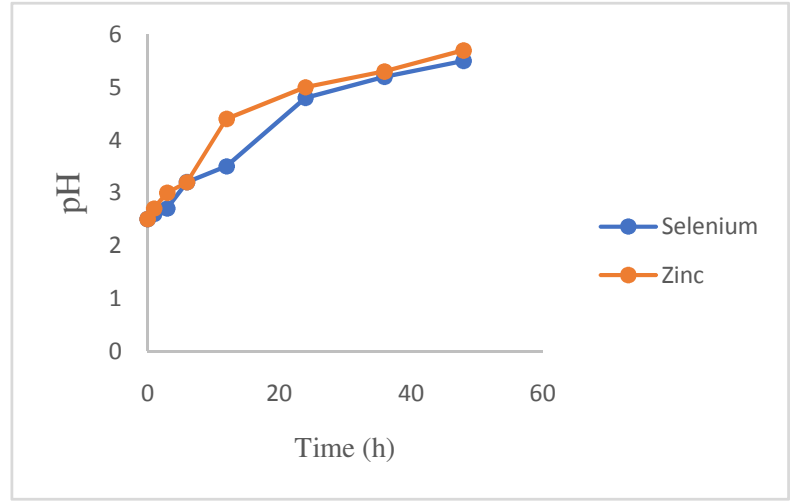

Figure 8: Change of $\mathrm{pH}$ of solution during batch test for 30 gr of zeolitic tuff.

ning of this experiment, it is hope that Se solution will behave differently compare to $\mathrm{Zn}$. This because, according to the theoritical review, Se will commonly neutral and have negative charged species on alkali condition and $\mathrm{Zn}$ have commonly positive charged species. But the results show that both heavy metals showing similar pattern. It seem that on acid condition (which apply on this batch test), Se will act similar as group of trace metals like $\mathrm{Cu}, \mathrm{Pb}$ and $\mathrm{Zn}$.

The change of $\mathrm{pH}$ on the solution is also measured on this experiment. The condition of $\mathrm{pH}$ at initial condition (time " 0 ") is in the acid condition representing $\mathrm{pH}$ water condition for acid mine water, during shaking for 48 hours with zeolitic tuff, the $\mathrm{pH}$ of solution are increase with time from about 2.5 to near 6.0 (see Figure 8). This information is also show that application of zeolitic tuff on "acid mine water" may also increase the $\mathrm{pH}$ of water not only adsorb the heavy metals content and this will very beneficiary. The buffering potential of zeolitic tuff may be comes from the dominated silicate group on this material.

\subsection{Sorption isoterm}

Result of the batch test for Se and $\mathrm{Zn}$, both found to be fit with the langmuir sorption isoterm. Linearization of the langmuir isotermof experimental data ( $30 \mathrm{gr}$ amount of zeolitic tuff) are shown in Figure 9 and Figure 10. The linear relationship is very high as shown by value of $R^{2}$ near 1.0. By applying the langmuir isoterm formula as shown in equation 5 , the $K_{d}$ value of zeolitic tuff for both metals is about 20 $\mathrm{ml} / \mathrm{g}$ and qm of about $0.06 \mathrm{mg} / \mathrm{g}$ (see Table 1). 


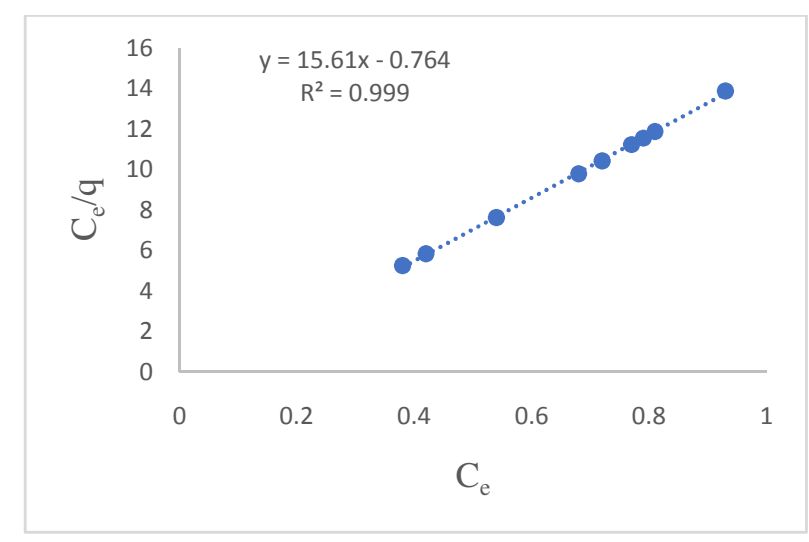

Figure 9: Linearization of langmuir sorption isoterm for batch test using 30 gr zeolitic tuff of Se solution.

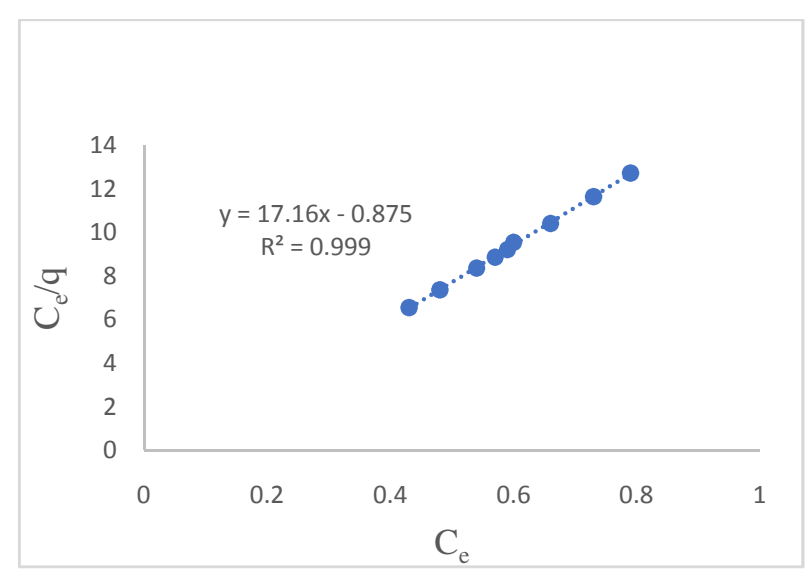

Figure 10: Linearization of langmuir sorption isoterm for batch test using $30 \mathrm{gr}$ zeolitic tuff of Zn solution.

Table 1: Summary of $K_{d}$ and $q_{m}$ from thebatch test experiments with 30 gr of zeolitic tuff.

\begin{tabular}{|c|c|c|}
\hline \multirow{2}{*}{ Parameter } & \multicolumn{2}{|c|}{ Heavy metals } \\
\cline { 2 - 3 } & Se & Zn \\
\hline$R^{2}$ & 0.99 & 0.99 \\
\hline$K_{d}(\mathrm{ml} / \mathrm{g})$ & 20.44 & 19.68 \\
\hline$q_{m}(\mathrm{mg} / \mathrm{g}$ & 0.064 & 0.058 \\
\hline$q=\frac{K_{d} C_{e}}{1+q_{m} C_{e}}$ & $q=\frac{20.44 C_{e}}{1+0.064 C_{e}}$ & $q=\frac{19.58 C_{e}}{1+0.058 C_{e}}$ \\
\hline
\end{tabular}

Based on the $K_{d}$ value, the retardation factor of zeolitic tuff can be estimated to be about 80 to 200 if we assume the bulk density ranges from 1.6 to $2.1 \mathrm{~g} / \mathrm{ml}$ and the porosity ranges from 0.2 to 0.4. This value show that zeolitic tuff is an effective immobilization materia for Se and $\mathrm{Zn}$. However, it should be bear on mind that this experiments were conducted under no competing ions. Application on different condition such as with competing ions (ex. Acid mine water) may revealed lower $\mathrm{Kd}$ and retardation factor.

The value of $q_{m}$ is $0.06 \mathrm{mg} / \mathrm{g}$ and this value represent the adsorption capacity of zeolitic tuff is good. Sorption capacity of zeolitic tuff to selenium is better compare to zinc. Higher sorption of Se than $\mathrm{Zn}$ probably due to differend charge species.

\section{CONCLUSION}

Natural zeolitic tuff from Gedangsari, Gunung Kidul are good sorbent for Selenium (Se) and Zinc $(\mathrm{Zn})$. High capability to sorb the metal due to the presence of zeoilitic and clay minerals. The mechanism of Se and Zn immobilization onto zeolitetuff probablyis not only physical sorption onto zeolitic and clay mineralsdue high surface area but also cation exchange from zeolitic minerals. The adsorption isotherm was fit on the Langmuir isotherm with the maximum of Se removal is $0.064 \mathrm{mg} / \mathrm{g}$ for Se and $0.058 \mathrm{mg} / \mathrm{g}$ for $\mathrm{Zn}$, respectively. Higher sorption of Se than $\mathrm{Zn}$ probably due to differend charge species. Therefore, zeolitic tuff from Gedangsari can be used as a reactive material for metal contaminated water especially by selenium and zinc.

\section{ACKNOWLEDGEMENTS}

Financial supports were provided by The Japanese International Cooperation Agency (JICA)who funded the ASEAN University Network/Southeast Asia Engineering Education Development Network (AUN/SEED-Net) Program.

\section{REFERENCES}

Ebby, G.N (2004) Principles of Environmental Geochemistry, Thomson-Brooks, $514 \mathrm{p}$.

Erdem, E., Karapinar, N., Donat, R. (2004) The removal of heavy metal cations by natural zeolites. J. Colloid Interface Sci., vol. 280, no. 2, pp. 309-314. 
Fatkhiandari, I.A. and Warmada, I.W. (2011) Studi Karakterisasi dan Genesa Zeolit Desa Tegalrejo, Kecamatan Gedangsari, Kabupaten Gunungkidul, Propinsi Daerah Istimewa Yogyakarta, Jurusan Teknik Geologi UGM, Unpublished.

Fetter, C.W. (1999) Contaminant Hydrogeology. $2^{\text {nd }}$ edition, Pearson Education (US), 500p.

Ghorbanloo, M., Ghamari, S., Yahiro, H. (2015) Encapsulation of copper (II) complexes with three dentate NO 2 ligands derived from 2, 6pyridinedicarboxylic acid in $\mathrm{NaY}$ zeolite, pp. 550-562.

Idrus, A., Titisari, A. D., Sudiyo, R., Soekrisno, R. (2008) Geology, characterization, quality improvement and recommended utilization of natural zeolite (zeolitic tuff) deposits from Gunung Kidul, Yogyakarta Special Province, Indonesia, pp. 21-25.

Khachatryan (2014) Heavy metal adsorption by Armenian natural zeolite from natural aqueous solutions, vol. 2, pp. 31-35.

Koohsaryan, E. and Anbia, M. (2016) Nanosized and hierarchical zeolites: A short review. Chinese Journal of Catalysis 37, pp. 447-467.

Limousin, G., Gaudet, J.-P., Charlet, L., Szenknect, S., Barthe's, V., Krimissa, M. (2007) Sorption isotherms: A review on physical bases, modeling and measurement, Applied Geochemistry 22, pp. 249-275.

Margeta, K., Logar, N.Z., Šiljeg, M., Farkas, A. (2013) Natural zeolites in water treatment - How effective is their use, Water Treatment, pp. 81-112.

Ozekmekci, M., Salkic, G., Fellah, M.F. (2015) Use of zeolites for removal of $\mathrm{H}_{2} \mathrm{~S}$ : a mini-review. Fuel Processing Technology 139, pp. 49-60.

Wang, S. and Peng, Y. (2010) Natural zeolites as effective adsorbents in water and wastewater treatment, vol. 156, pp. 11-24.

Widiasmoro and Wintolo, D. (2000) Pekerjaan pembuatan profil zeolit di Desa Sampang, Kabupaten Gunungkidul, Daerah Istimewa Yogyakarta sebagai bahan penjernih minyak kelapa sawit. Dinas Pertambangan DIY-Jurusan Teknik Geologi FT. UGM, p.59, Unpublished.

Wilopo, W., Haryono, S.N., Putra, D.P.E., Warmada, I.W., Hirajima, T. (2010) Copper $\left(\mathrm{Cu}^{2+}\right)$ removal from water using natural zeolite from Gedangsari. J. SE Asian Appl. Geol., May-Aug 2010, vol. 2(2), pp. 117-120.

Yuminti, S. (2005) Karakteristik dan potensi batuan mengandung zeolit di daerah Bantengwareng, Kecamatan Gedangsari, Kabupaten Gunung kidul. Jurnal Saintifika Gadjah Mada, vol. 2, no. 1 , pp. $40-50$. 